Review Article

\title{
Occupational stress of nurses in emergency care: an integrative review of the literature
}

\author{
Estresse ocupacional dos enfermeiros de urgência e emergência: Revisão Integrativa da Literatura \\ Estrés laboral de los enfermeros de urgencia y emergencia: revisión integradora de literatura
}

\author{
Francimar Nipo Bezerra ${ }^{1}$, Telma Marques da Silva², Vânia Pinheiro Ramos ${ }^{3}$
}

\begin{abstract}
Objective: Toanalyze the scientific literature related to the way in which occupational stress is present in the life of a nurse who works in an emergency care setting.Methods: Weperformed an integrative review of the literature using the Bdenf, Lilacs, Medline, and Pubmed databases, and the Scielo repository.The inclusion criteria for sample selection were: articles published in Portuguese and English which reflected the theme of the study, published and indexed in these databases within the last 10 years.Results:We selected eight articles. The results indicated that the occupational stress of nurses in emergency care is related to the scarcity of human resources and number of hours worked, the physical plant and inadequate material resources, as well as night shifts, the work-home interface, interpersonal relationships, competitive work climate, and the gap between theory and practice.Conclusion:The meaning of work for professionals contributes to their protection against suffering and occupational stress.
\end{abstract}

Keywords: Emergency nursing; Prehospital care; Burnout professional; Occupational health nursing

\section{RESUMO}

Objetivo: Analisar a produção científica relacionada ao modo como o estresse ocupacional está presente na vida do enfermeiro que atua no cenário da urgência e emergência. Métodos: Foi realizada uma revisão integrativa da literatura nas bases de dados Bdenf, Lilacs, Medline, Pubmed e no repositório Scielo. Os critérios de inclusão para a seleção da amostra foram: artigos publicados em português e inglês que retratassem a temática em estudo, publicados e indexados nas referidas bases nos últimos 10 anos. Resultados: Foram selecionados oito artigos. Os resultados apontaram que o estresse ocupacional dos enfermeiros de urgência e emergência está relacionado à escassez de recursos humanos e à carga horária de trabalho, instalações físicas e recursos materiais inadequados, além de plantões noturnos, interface trabalho-lar, relacionamentos interpessoais, trabalho em clima de competitividade e distanciamento entre teoria e prática. Conclusão: O sentido do trabalho para os profissionais contribui para sua proteção contra o sofrimento e o estresse ocupacional.

Descritores: Enfermagem em emergência; Assistência pré-hospitalar; Esgotamento profissional; Enfermagem do trabalho

\section{RESUMEN}

Objetivo: Analizar la literatura científica relacionada de cómo el estrés laboral está presente en la vida del enfermero que trabaja en el ámbito de la urgencia y emergencia. Métodos: Se llevó a cabo una revisión integrativa de la literatura en las bases de datos Bdenf, Lilacs, Medline, PubMed y repositorio Scielo. Los criterios de inclusión para la selección de la muestra fueron: artículos publicados en portugués e inglés que retraten la temática en estudio, publicados e indexados en las referidas bases en los últimos 10 años. Resultados: Fueron seleccionados ocho artículos. Los resultados señalaron que el estrés ocupacional de los enfermeros de urgencia y emergencia está relacionado a la escasez de recursos humanos y a la carga horaria de trabajo, instalaciones físicas y recursos materiales inadecuados, además de guardias nocturnas, interface trabajo-hogar, relaciones interpersonales, trabajo en clima de competitividad y distanciamiento entre teoría y práctica. Conclusión: El sentido del trabajo para los profesionales contribuye para su protección contra el sufrimiento y el estrés ocupacional.

Descriptores: Enfermería de urgencia; Atención prehospitalaria; Agotamiento profesional; Enfermería del trabajo

\footnotetext{
${ }^{1}$ Graduate student (Master's) of the Graduate Program, Department of Nursing, Federal University of Pernambuco - UFPE - Recife (PE), Brazil.

${ }^{2}$ Doctorate in nursing. Associate Professor, Department of Nursing, Federal University of Pernambuco - UFPE - Recife (PE), Brazil.

${ }^{3}$ Doctorate in Neuropsychiatry and Behavioral Science. Associate Professor, Department of Nursing, Federal University of Pernambuco - UFPE - Recife (PE), Brazil.
} 


\section{INTRODUCTION}

Occupational stress is generated by factors related to work, which constitute a set of activities filled with values, intentions, behaviors and representations. The work enables growth, transformation, recognition and personal independence; however, the constant changes imposed on individuals may also generate problems such as insecurity, dissatisfaction, disinterest and irritation ${ }^{(1,2)}$.

In this sense, the work can favor both health and illness. Thus, the work in health, despite technological advances, remains supported by intensive labor and with unequal levels of mastery of the components that interact in the process. However, comprehension of the relationship between work and health depends on the meaning that workers attribute to their situation ${ }^{(3) .}$ The majority of the professionals working in urgent and emergency care settings appreciate the reality of dealing with the unexpected, and this is considered a protective factor against occupational stress.

An interpersonal relationship can influence the lifestyle of health professionals.In this process, the nurse has to work both as an agent and as a subject of action of man himself: but s/he must work in a normalized, fragmented way, with excessive responsibility, rotation of shifts and the need for constant expansion of knowledge ${ }^{(4,5)}$. These stress factors, when added to the factor of time, can lead to illness in the professionals.

Considering this context, the role of the nurse in urgent and emergency care is evaluated as a trigger of physical and emotional wear and stress, since the environment in which $\mathrm{s} /$ he operates includes the joint action of a multidisciplinary team, committed to the requirements of the work process, and responsible for the well-being and lives of patients ${ }^{(6,7)}$.

Health professionals who work in urgent and emergency care, on a daily basis, are confronted with situations that require such rapid conduct that, at times, simultaneous actions are demanded without prior planning.Therefore, they require knowledge, self-control and efficiency in providing patient care, in order not to commit errors.

Therefore these professionals are constantly dealing with the imminent risk of death, in which the complexity of the care provided, coupled with personal factors, havea frequent relationship with the onset of $\operatorname{stress}^{(2,7,8)}$. Therefore, these stressors should be identified so that methods of coping are adopted, in order to avoid or minimize illness.

According to the World Health Organization (WHO) in 2012, 90\% of the world population is affected by stress, because we live in a time of great demands to update, and the constant necessity of dealing with new information ${ }^{(9)}$. This growing concern is strongly present in the nursing field, considered by the Health Education Authority ${ }^{(7,10-11)}$ to be the fourth most stressful profession in the public sector.

Stress is related to subjectivity, both in the perception of its occurrence and the individual's response to it.This can be verified in the urgent and emergency care environment in which the nurse experiences unpredictable situations involving tension, fear, suffering and death, which can trigger occupational stress.

In this context, nurses require knowledge, effort and skills, ${ }^{(4-6,11)}$ as well as rapid and effective decision-making ${ }^{(6)}$. In this situation, stress arises as a complex and dynamic physiological and psychological response in the body, triggered when the individual is faced with stressors, which may produce physical and psychological diseases.Thus, occupational stress is determined by the perception of the professional about his/her work demands as stressors, and by his/her ability to face them ${ }^{(4-6,8-12)}$.

Thus, the stressor is a factor that generates feelings of tension, anxiety, fear or threat, and may have an internal or external origin. The damage provoked by these factors depends on the vulnerability of every human being, personality, culture, and values, among others ${ }^{(6)}$.

Studies have shown that when faced with a stressor, the body experiences three phases: in the first, a phase of alarm or alert, the body identifies the stressor and activates the neuroendocrine system.The second phase, of adaptation or resistance, is the moment in which the body repairs damage caused by the alarm reaction and reduces hormonal levels. The third phase occurs if the stressor remains present, this is the phase of exhaustion, that comprises the onset of a disease associated with stress ${ }^{(1,7)}$.

Therefore, it is important that nurses who work in an urgent and emergency care setting recognize the stressors in their work environments, and their repercussions on the health-disease process, and seek solutions to mitigate them and face them, preventing damage to their health and guaranteeing good care for their patients ${ }^{(6)}$. Knowledge of this process is relevant, however, it is considered that the meaning that professionals confer upon their work is a protective factor against illnesses.

These strategies of confrontation are known as coping,meaning ways to handle, and coping includes creating conditions and possibilities for the situations with which professionals are confronted, entailing the lowest impacton their health, their coworkers and their patients ${ }^{(\sigma)}$.

In this perspective, BurnoutSyndromeor Professional Exhaustion Syndrome, arises as one of the results of the failure of coping strategies, this being one of the main consequences of occupational stress. So when this syn- 
drome is not treated adequately, it can lead individuals to death.Nursing, due to its being in direct contact with the feelings and problems of other people, is one of the most affected professions ${ }^{(7,13)}$.

The importance of scientific investigations related to occupational stress of the nurse in urgent and emergency care settings is based on the relationship to suffering and illness provoked in the professional, thereby justifying the development of this integrative review.In this research, nurses in emergency, pre-hospital care, occupational stress and occupational health nursing were used as pillars of the study.

\section{OBJECTIVE}

To analyze the scientific production related to the way in which occupational stress is present in the life of a nurse who works in the urgent and emergency care setting.

\section{METHODOLOGICAL PROCEDURES}

In this study, we performed an integrative literature review, defined as one in which the published research studies are synthesized and conclusions are generated about the theme under study. The development of an integrative review includes six steps: selection of the hypotheses or questions for review, definition of the criteria for sample selection, definition of the characteristics of the original research, data analysis, interpretation of the results, and presentation of the review ${ }^{(6,14)}$.

The question guiding this research was: What is the scientific production that relates to how occupational stress is present in the life of a nurse who works in the urgent and emergency care setting?

To search for the articles, the following databases were used: Latin American and Caribbean Health Sciences Literature (LILACS), Medical Literature Analysis and Retrieval System On-line (MEDLINE), Database of Nursing (Bdenf), National Library of Medicine, USA (Pubmed), and the Scientific Electronic Library Online repository (SciELO).

In order to collect the articles, the descriptors "emergency nursing", "pre-hospital care", "occupational stress", "occupational health nursing" were used.Initially, a search for the descriptors individually was conducted.Next, we performed the intersections between terms, using the Boolean operator $A N D$. Later, the three descriptors were utilized all together.The inclusion criteria for sample selection were: articles published in Portuguese and English, published and indexed in the aforementioned databases in the last ten years, and which reflect the theme of the study.Table 1 demonstrates the search strategy utilized.
Table 1. Publications encountered between the years 2001 and 2010, according to the databases Bdenf, Lilacs, Medline and Pubmed

Descriptors

BDENF LILACS MEDLINE PUBMED

\begin{tabular}{|c|c|c|c|c|}
\hline Occupational stress & 25 & 112 & 2279 & 122 \\
\hline Prehospital care & 8 & 14 & 0 & 1 \\
\hline Emergency nursing & 76 & 78 & 2648 & 4 \\
\hline $\begin{array}{l}\text { Occupational } \\
\text { health nursing }\end{array}$ & 97 & 117 & 666 & 8 \\
\hline $\begin{array}{l}\text { Occupational } \\
\text { stressand } \\
\text { prehospital care }\end{array}$ & 0 & 1 & 0 & 0 \\
\hline $\begin{array}{l}\text { Occupational stress } \\
\text { and emergency } \\
\text { nursing }\end{array}$ & 2 & 2 & 23 & 0 \\
\hline $\begin{array}{l}\text { Occupational stress } \\
\text { and occupational } \\
\text { health nursing }\end{array}$ & 5 & 5 & 10 & 0 \\
\hline $\begin{array}{l}\text { Prehospital care } \\
\text { and emergency } \\
\text { nursing }\end{array}$ & 0 & 1 & 0 & 0 \\
\hline $\begin{array}{l}\text { Prehospital care and } \\
\text { occupational nursing }\end{array}$ & 0 & 0 & 0 & 0 \\
\hline $\begin{array}{l}\text { Emergency nursing } \\
\text { and occupational } \\
\text { health nursing }\end{array}$ & 3 & 3 & 1 & 1 \\
\hline All & 0 & 0 & 0 & 0 \\
\hline
\end{tabular}

The strategies used for the choosing of the articles were adapted for each of the databases, according to their specific features of access, and driven by the guiding question and inclusion criteria.In order to select the articles, all titles were read and those that were related to the study objective were selected. Then, the abstracts were analyzed and articles were selected to read in full that were related to the theme under study.In sum, forty articles were read, and eight were selected that responded to the question guiding the study, and that fit the inclusion criteria of the integrative review.

The bibliographic reviews occurred in the months of September and October, 2011. The retrieved articles were listed by the order of their location, identified and presented in accordance with standards of bibliographical reference. For the organization of the articles, a data collection form was completed, according to the previously validated model ${ }^{(15)}$. After use, these were placed in a folder and catalogued in ascending numerical order.

The selected material was treated by means of cataloging, which provided an initial approach to the subject. 
Further, the articles were subjected to rereading, in order to perform an interpretative analysis, driven by the guiding question.For data analysis, thematic categories were created according to the grouping of content encountered, relating to occupational stressors that affect nurses working in urgent and emergency care settings.

\section{RESULTS}

In this integrative review, we analyzed eight scientific articles that met the inclusion criteria previously established. The data in Table 2 presents a summary of the characteristics of the studies included.

Table 2. Presentation of the characteristics of the articles included in integrative review

\begin{tabular}{|c|c|c|c|c|}
\hline Title & Author (s) & $\begin{array}{l}\text { Year / } \\
\text { Country }\end{array}$ & $\begin{array}{l}\text { Study } \\
\text { Design }\end{array}$ & Findings \\
\hline $\begin{array}{l}\text { Stress and coping strategies } \\
\text { in a team of nurses in } \\
\text { emergency care. }\end{array}$ & $\begin{array}{l}\text { Calderero } \\
\text { ARL, Miasso } \\
\text { AI, Corradi- } \\
\text { WebsterCM. }\end{array}$ & 2008 / Brazil & $\begin{array}{l}\text { Descriptive,cross- } \\
\text { sectional with quali- } \\
\text { quantitative approach }\end{array}$ & $\begin{array}{l}\text { Stress presented by these professionals } \\
\text { must be accompanied by efforts to cope, } \\
\text { so that the individual maintains a stable } \\
\text { level of homeostatic functioning. }\end{array}$ \\
\hline $\begin{array}{l}\text { Work under urgency } \\
\text { and emergency and its } \\
\text { relationship with the health } \\
\text { of nursing professionals. }\end{array}$ & $\begin{array}{l}\text { Pai DD, Lautert } \\
\text { L. }\end{array}$ & 2008 / Brazil & Qualitative, descriptive & $\begin{array}{l}\text { The benefit of work on the health of } \\
\text { nursing professionals isfound in the } \\
\text { symbolic value attributed to the action. }\end{array}$ \\
\hline $\begin{array}{l}\text { Stressors and coping:nurses in a } \\
\text { hospital emergency unit. }\end{array}$ & $\begin{array}{l}\text { Silveira MM, } \\
\text { Stumm EMF, } \\
\text { Kirchner RM. }\end{array}$ & 2009 / Brazil & $\begin{array}{l}\text { Transversal, } \\
\text { quantitative, analytical }\end{array}$ & $\begin{array}{l}\text { The management of occupational stress } \\
\text { could impact the improvement of the } \\
\text { performance of nurses. }\end{array}$ \\
\hline $\begin{array}{l}\text { Stressors and coping } \\
\text { experienced by nurses in a } \\
\text { service of prehospital care. }\end{array}$ & $\begin{array}{l}\text { Stumm EMF, } \\
\text { Oliveski CCO, } \\
\text { Costa CFL, } \\
\text { Kirchner RM, } \\
\text { Silva LAA. }\end{array}$ & 2008 / Brazil & $\begin{array}{l}\text { Quantitative, } \\
\text { descriptive and } \\
\text { exploratory type }\end{array}$ & $\begin{array}{l}\text { The identification of stressors can } \\
\text { facilitate effective coping actions to deal } \\
\text { with occupational stress. }\end{array}$ \\
\hline $\begin{array}{l}\text { Stress among emergency unit } \\
\text { nurses. }\end{array}$ & $\begin{array}{l}\text { Batista KM, } \\
\text { Bianchi ERF. }\end{array}$ & 2006 / Brazil & $\begin{array}{l}\text { Quantitative, } \\
\text { exploratory, descriptive } \\
\text { type }\end{array}$ & $\begin{array}{l}\text { The nurse is a professional who lives with } \\
\text { stressful working conditions. }\end{array}$ \\
\hline $\begin{array}{l}\text { Influence of stress on the } \\
\text { occupational health of } \\
\text { nurses who work in hospital } \\
\text { emergency. }\end{array}$ & $\begin{array}{l}\text { Valente GSC, } \\
\text { Martins CC. }\end{array}$ & 2010 / Brazil & $\begin{array}{l}\text { Qualitative, exploratory } \\
\text { and descriptive type }\end{array}$ & $\begin{array}{l}\text { Symptoms and signs that are presented by } \\
\text { the nursing professionals are related to the } \\
\text { triggering factors of burnout syndrome. }\end{array}$ \\
\hline $\begin{array}{l}\text { Stress of the nursing staff in } \\
\text { an emergency clinic. }\end{array}$ & $\begin{array}{l}\text { Panizzon C, } \\
\text { Luz AMH, } \\
\text { Fensterseifer LM. }\end{array}$ & 2008 / Brazil & $\begin{array}{l}\text { Quantitative, } \\
\text { exploratory }\end{array}$ & $\begin{array}{l}\text { Necessity for change management in the } \\
\text { emergency department to reduce the stress } \\
\text { of these professionals. }\end{array}$ \\
\hline $\begin{array}{l}\text { Stress and coping in the } \\
\text { workplace. }\end{array}$ & Kovacs M. & 2007 / USA & $\begin{array}{l}\text { Observational, } \\
\text { descriptive }\end{array}$ & $\begin{array}{l}\text { Dealing with stress in the workplace } \\
\text { will require psychologists and corporate } \\
\text { consultants to devise coping strategies. }\end{array}$ \\
\hline
\end{tabular}

\section{DISCUSSION}

Stress is generated by the perception of stimuli that provoke emotional excitation and disruption of homeostasis, therefore triggering a process of adaptation characterized by physiological and psychological disturbances ${ }^{(16-18)}$. The International LaborOrganization (ILO) considers occupational stress to be a set of phenomena that appear in the body and which can affect health ${ }^{(19)}$, resulting in different responses among individuals.

The urgent and emergency care setting is characterized by: the high demand of patients with risk for imminent death, occurrences of an unpredictable nature, long working hours, pressure of management, a collection of family members, and reduced time for the provision of assistance.In some situations, even the safety of the team is put to the test, for example, in occurrences of physical aggression without the support of the Military Police, generating situations of increasing occupational stress.

After analysis, seven categories were constructed, according to the grouping of the content related to how occupational stress is present in the life of the nurse who works in the urgent and emergency care setting. 


\section{Scarcity of human resources}

The deficit of staff was identified as a negative factor in the workplace and was related to an overload of activities, accounting for psychological distress and occupational stress.Professionals are driven to accumulate functions, and, sometimes, improvise their work or exercise it in an incomplete form and at an accelerated rhythm ${ }^{(1-3,12,13,18)}$. Responsibility for more than one function is stressful and can generate lack of motivation, due to work overload and the inability to comply with all of the tasks ${ }^{(4)}$.

In this sense, other studies corroborate the affirmation that this situation creates delicate decision making, mobilizing a strong affective burden, which is necessary to make radical adaptations in the process of work under precarious conditions ${ }^{(20,21)}$.

Also in this direction, the setting of urgent and emergency care requires nursing professionals to develop activities that demand physical exertion, which, when added to the precariousness of these professionals, leads to a fall in the quality of care provided ${ }^{(1,4)}$.

\section{Hours of work}

The compliance with an elevated weekly workload is considered stressful by nurses, because it means elevated productivity and greater energy expenditure.This excess of work is indicative of an imbalance between the individual and his/her job, compromising quality of life, shaking the relationships with colleagues, and creating "wear and tear" ${ }^{(4,6,7)}$. This result is corroborated by the statement that time spent on the activity is, in itself, a stress element ${ }^{(21)}$.

In this context, the high workload causes disequilibrium in the physical and mental health of the professional, triggering difficulties in dealing with everyday situations in the work environment, requiring greater capacity to direct attention to decision-making and problem solving in the exercise of one's functions ${ }^{(7)}$.

This situation is aggravated by the current crisis in the health sector, which affects the work environment, with low wages, so that professionals are driven to maintain more than one job ${ }^{(2,4,6,7,21)}$. However, when this workload is performed only in emergency, the stress is smaller than when performed in services of different natures $^{(6,7,13)}$. The dissatisfaction with the low wages is also corroborated with the emergence of burnout syndrome in Brazilian nursing ${ }^{(6,7)}$.

Material resources and inadequate infrastructure

Working with inadequate material resources and physical facilities is considered a stress factor for health professionals ${ }^{(1,3,4,6,13,14,19)}$. This lack of material work resources provokes improvisation and the procuring of materials from other sectors, which, when permitted, causes loss of time, mental and physical fatigue.
In these urgent and emergency care settings, agility and efficiency in the performance of activities, also guaranteed by the availability of necessary materials and an adequate physical space, contribute to the good prognosis of the patient, being indispensable to their care in a timely manner ${ }^{(21,23)}$.

\section{Night shifts}

The night shifts are considered a stressor, since night work provides continuous sleep deficit, vigilance problems and mood alterations.It also predisposes one to a risk to the quality of care, social isolation with repercussions on the family or other social segments, and dissonance in coexistence in relation to working hours, among other issues ${ }^{(2,4,6,7)}$. Thus, the work performed in nocturnal hours does not provide a good quality of life for professionals.

\section{Work-home interface}

Reconciling issues experienced at work with the work in the home is considered stressful, because the nursing profession consists predominantly of women who live with the dynamic of development of its activities and managing their lives as wives, mothers and people $e^{(2,4,8)}$. On the other hand, authorsaffirm that the work-home interface, instead of being a stressor, can function as support or a protective factor ${ }^{(21)}$.

\section{Interpersonal relationships}

In some situations, an interpersonal relationship is considered a stressor ${ }^{(4,6,13)}$, and dissatisfaction may result from interpersonal relations of conflicting hierarchies ${ }^{(21,22)}$.

Interpersonal conflicts are inherent in the relationships between people, and should not be considered negative factors, since some conflicting situations become important, as signals of changes, allowing them to be rethought and modified as modes of action ${ }^{(4,6,13)}$.

In the urgent and emergency care setting, the division of labor can be mitigated by the necessity to act intellectually given the risk of imminent death ${ }^{(2,3)}$, thus resulting in a smaller number of conflicts.

\section{Working in a competitive climate}

Studies showed that the necessity to perform procedures in minimal time, coupled with the instability of the situation of critically ill patients, is considered crucial to the stress generated in urgent and emergency situations ${ }^{(4,12)}$. Also in this perspective, meeting deadlines, participation at important meetings ${ }^{(23)}$ and the level of severity of the patient are noted in another study ${ }^{(21)}$.

Working in a competitive atmosphere is a stressor, and this is a remarkable factor in the current context of human relationships.Large requirements generate negative repercussions on the psychic health of professionals ${ }^{(4,6,24)}$. 


\section{Gap between theory and practice}

The gap between theory and practice is also referred to as a stressor.Although educational institutions have the role of preparing professionals for practice, every professional must continually seek his/her own improvement and growth ${ }^{(4)}$.

Another stress factor identified was the fulfillment of activities by professionals whose academic training is focused on patient care, beyond the fact that they worked in an environment full of critically ill patients ${ }^{(1,6,12)}$. In this context, reconciling bureaucratic activities with the care of seriously ill patient results in distancing nursing staff from direct care, generating further changes for this professional.

For many professionals, working with an unprepared team is also considered to be a great stress generator, since work in the urgent and emergency care setting requires knowledge, skill and dexterity in performing procedures in which time is critical ${ }^{(6,12)}$.

Given the diversity of the urgent and emergency care setting, and the quantity of stressors present, it is of critical importance for the nurses to recognize these factors, so they can adopt methods for coping.

\section{REFERENCES}

1. Batista KM, Bianchi ER. Estresse do enfermeiro em unidade de emergência. Rev Latinoam Enferm. 2006; 14(4): 534-9.

2. Dalri RC, Robazzi ML, Silva LA. [Occupational hazards and changes IF health among brazilian professionals nursing from urgency and emergency units]. Cienc Enferm. 2010; 16(2):69-81. Portuguese.

3. Dal Pai D, Lautert L. Work under urgency and emergency and its relation with the health of nursing professionals. Rev Latinoam Enferm. 2008; 16(3):439-44.

4. Silveira MM, Stumm EM, Kirchner RM. Estressores e coping: enfermeiros de uma unidade de emergência hospitalar. Rev Eletrônica Enferm. 2009; 11(4): 894-903.

5. Oliveira EM, Spiri WC. [Personal dimension of the work process for nurses in intensive care units]. Acta Paul Enferm. 2011; 24(4): 550-5.

6. Stumm EM, Oliveski CC, Costa CF, Kirchner RM, Silva LA. Estressores e coping vivenciados por enfermeiros em um serviço de atendimento pré-hospitalar. Cogitare Enferm. 2008; 13(1):33-43.

7. Panizzon C, Luz AM, Fensterseifer LM. Estresse da equipe de enfermagem de emergência clínica. Rev Gaúch Enferm. 2008; 29(3):391-9.

8. Paschoal T, Tamayo A. [Impacto f work values and family work interference on occupational stress]. Psicol Teor Pesqui. 2005; 21(2):173-80. Portuguese.

9. Bauer ME. Estresse: como ele abala as defesas do organismo. Ciênc Hoje. 2002; 30(179): 20-5.

10. Murofuse NT, Abranches SS, Napoleão AA. [Reflections on stress and Burnout and their relationship with nursing] Rev Latinoam Enferm. 2006; 13(2): 255-61. Portuguese.

11. Benavente SB, Costa AL. Physiological and emotional responses to stress in nursing students: an integrative review of scientific literature. Acta Paul Enferm. 2011; 24(4): 571-6.

\section{CONCLUSION}

The most frequently reported occupational stressors by nurses working in urgent and emergency care environments are: scarcity of human resources, material resources and inadequate physical facilities; number of hours worked; night shifts; work-home interface; interpersonal relationships; working in a competitive climate; and the gap between theory and practice.

However, it is known that one aspect that contributes to protection against suffering and stress in the work environment is the meaning that individuals attribute to the work. The peculiarities of the urgent and emergency care settings require initiative, the capacity to make decisions rapidly, and technical proficiency, providing a sense of privilege and satisfaction to professionals.

We highlight the importance of recognizing stressors and their effects on the body so that methods are adopted in order to avoid facing psychological and physiological disturbances.

We suggest that health institutions create moments and environments for professionals to share experiences and feelings experienced during their work shifts.

12. Valente GS, Martins CC. Influence of the stress in the occupational nurses' health who works in hospital emergency. Rev Enferm UFPE on-line. 2010; 4(2): 533-8.

13. Dalmolin GL, Lunardi VL, Lunardi Filho WD. [Moral distress of nursing workers in their Professional exercise] Rev Enferm UERJ. 2009; 17(1): 35-40. Portuguese.

14. Silveira CS. Pesquisa em enfermagem oncológica no Brasil: uma revisão integrativa [dissertação]. Ribeirão Preto: Universidade de São Paulo, Escola de Enfermagem; 2005.

15. Souza MT, Silva MD, Carvalho R. Revisão integrativa: o que é e como fazer. Einstein (São Paulo). 2010; 8(1 Pt 1):102-6.

16. Margis R, Picon P, Cosner AF, Silveira RO. Relação entre estressores, estresse e ansiedade. Rev Psiquiatr. 2003; (Supl 1): 65-74.

17. Cortez CM, Silva D. Implicações do estresse sobre a saúde e a doença mental. ACM Arq Catarin Med. 2007; 36(4):96-108.

18. Calderero AR, Miasso AI, Corradi-Webster CM. Estresse e estratégias de enfrentamento em uma equipe de enfermagem de Pronto Atendimento. Rev Eletrônica Enferm. 2008; 10(1):51-62.

19. Costa JR, Lima JV, Almeida PC. [Stress the nurse's work]. Rev Esc Enferm USP. 2003; 37(3):63-71.Portuguese.

20. Salomé GM, Martins MF, Espósito VH. Sentimentos vivenciados pelos profissionais de enfermagem que atuam em unidade de emergência. Rev Bras Enferm.2009; 62(6):856-62.

21. Stacciarini JM, Tróccoli BT. O estresse na atividade ocupacional do enfermeiro. Rev Latinoam Enferm. 2001; 9(2): 17-25.

22. Kovacs M. Stress and coping in the workplace. Psychologist. 2007; 20(9):S48-50

23. Hanzelmann RS, Passos JP. Nursing images and representations concerning stress and influence on work activity. Rev Esc Enferm USP 2010; 44(3): 694-701.

24. Araújo TM, Graça CC, Araújo E. Occupational stress and health: contibutions of the demand-control model. Ciênc Saúde Coletiva. 2003; 8(4):991-1003. 